\title{
KASVATUS\&AIKA
}

\section{Opettajan asiantuntijuus muutoksessa - asiantuntijuus ja sen jakamisen diskurssit digitaalisessa oppimisympäristössä}

\author{
Jenni Huhtasalo
}

Asiantuntijuus ja asiantuntijatyö on perinteisesti liitetty spesifeihin ammattialoihin ja professionaalisuuteen. Teknologian lisääntyvä käyttö asiantuntijatyössä kuitenkin muuttaa asiantuntijuuden ilmenemistä ja sen rajoja. Tässä artikkelissa tarkastelen yliopisto-opettajien ja opiskelijoiden haastattelupuheesta sitä, miten asiantuntijuutta tuotetaan erilaisten puhetapojen avulla ja miten asiantuntijuutta jaetaan, kun sosiaalityöntekijäopiskelijoiden kandidaatintyön ohjaus tapahtuu verkon välityksellä. Asiantuntijuuden käsitteen jaoin kolmeen eri osa-alueeseen: teknologiseen, sisällölliseen sekä tieteelliseen asiantuntijuuteen. Analysoin aineistoa sisällön analyysin ja diskurssianalyyttisen otteen avulla. Kolmella tutkimallani asiantuntijuuden osaalueella esiintyi opettajien ja opiskelijoiden puheessa neljä erilaista puhetapaa, joilla asiantuntijuutta tuotettiin ja jaettiin. Puhetavat nimesin 1) ikädiskurssiksi 2) opettajuusdiskurssiksi 3) työkokemusdiskurssiksi ja 4) kokemattomuusdiskurssiksi. Tutkimukseni osoitti, että näiden diskurssien kautta jaettiin opettajien ja opiskelijoiden kesken teknologista ja sisällöllistä asiantuntijuutta. Tieteellinen asiantuntijuus jäi puhetavoissa jakamattomaksi vain opettajille kuuluvaksi asiantuntijuuden osa-alueeksi.

\section{Johdanto}

Opetus- ja oppimistilanteet ovat entistä monimuotoisempia, ja opetusteknologian käyttö yliopistolla työskentelevien opettajien arjessa on lisääntynyt ja kehittynyt (Nevgi ym. 2002; Keurulainen ym. 2014). Opiskeluympäristöjen teknologisoituminen mahdollistaa opiskelun ajasta ja paikasta riippumatta. Lisäksi internetin tarjoama nopea pääsy valtavan tietomäärän äärelle ja tiedon jakamisen erilaiset muodot haastavat opettajien työtä yhdessä uudenlaisen, verkkovälitteisen vuorovaikutuksen kanssa (Korhonen \& Koivisto, 2007; Tseng \& Kuo 2014; Michos \& Hernández-Leo 2020). Nämä muutokset sekä ulkoapäin tulevat opettajan 
asiantuntijuuteen ja rooliin kohdistuvat vaatimukset lisäävät opettajan työn paineita. Ulkoiset vaatimukset liittyvät entistä haastavampiin opiskelijoihin sekä monialaiseen päätöksentekoon ja resurssien käytön ja allokoinnin suunnitteluun, johon opettajat osallistuvat opetustyönsä lisäksi (Husu \& Toom 2010, 132-135; Murtonen 2017). Voidaan väittää, että opettajan työssä tapahtunut muutos kyseenalaistaa vallitsevaa käsitystämme opettajan ammatin professionaalisesta luonteesta (Conole 2013; Tseng \& Kuo 2014; Michos \& Hernández-Leo 2020), ja tämä on synnyttänyt keskustelua uudesta opettajuudesta ja uusista asiantuntijuuden määritelmistä (ks. Keurulainen ym. 2014; Suárez-Rodríguez ym. 2018).

Opetustyössä käytettävään teknologiaan liittyvä tutkimus on varsin laajaa ja melko normatiivista. Se painottuu teknologian integroinnin pedagogiseen kehittämiseen (Jalkanen \& Taalas 2015; Laaksonen 2016), verkon välityksellä tapahtuvan ohjauksen ja oppimisen tukemiseen (Laurillard 2012) ja teknologian opetuskäytön yleiseen tarkasteluun (Gil-Flores ym. 2017). On selvää, että opetusteknologialla on vaikutusta oppimisympäristöihin, opetukseen ja opiskeluun sekä myös opettajan identiteettiin ja asiantuntijuuteen (Laurillard 2012; Heikkilä-Tammi \& Viteli 2017; Michos \& Hernández-Leo 2020). Asiantuntijuuden ollessa jatkuvassa muutoksen tilassa (Launis \& Engeström 2005 [1999]), sitä ei ole enää mielekästä määritellä yhden asiantuntijayksilön tai -ryhmän pysyväksi ominaisuudeksi (Edwards 2010; Michos \& Hernández-Leo 2020). Juuri asiantuntijuuden muutostila ja teknologian lisääntyvä käyttö opetustyössä tekee opettajan asiantuntijuuden tutkimuksesta ajankohtaista ja tärkeää. Asiantuntijuuden muutoksen ymmärtämiseksi on tarpeen tutkia, mitä haasteita teknologian kasvava käyttö opetustilanteissa tuo opettajalle asiantuntijana, ja miten asiantuntijuutta jaetaan yksittäisen asiantuntijaryhmän, kuten yliopisto-opettajien, ulkopuolelle (ks. esim. Pelttari ym. 2017; Jalkanen \& Taalas 2015). Tutkimuksessani tarkastelen yliopisto-opettajien ja opiskelijoiden haastattelupuheesta, miten asiantuntijuutta tuotetaan erilaisten puhetapojen avulla ja miten asiantuntijuutta jaetaan, kun sosiaalityöntekijäopiskelijoiden kandidaatintyön ohjaus tapahtuu verkon välityksellä. Tutkimukseni tavoitteena on osallistua keskusteluun opettajan professiosta ja sen etsimisestä muutosten keskellä.

\section{Asiantuntijuus ja jaettu asiantuntijuus}

Asiantuntijuus-käsitteeseen liittyviä määritelmiä on tutkimuskirjallisuudessa runsaasti. Asiantuntijuuden erilaisia muotoja, kuten suljettua, avointa, kollektiivista, hajautettua ja relationaalista asiantuntijuutta on tutkittu laajasti eri näkökulmista ja teoriasuuntauksista käsin (ks. Saaristo 2000; Parviainen 2006; Stenius ym. 2016; Edwards 2017). Termeille "asiantuntijuus" (expertise) ja "jaettu asiantuntijuus" (shared expertise, distributed expertise) on suomeksi eri käännöksiä, ja niiden merkityksiä luodaan aina uudelleen eri aikakonteksteissa. Näin ollen asiantuntijuuden kuvaaminen tyhjentävästi vain yhdellä suomenkielisellä käsitteellä on vaikeaa (Collin 2010). Tutkimukseni linkittyy osaksi monimuotoista professioiden sosiologian tutkimusperinnettä, tarkemmin sanoen uuden eksperttiyden (Saaristo 2000; Giddens 1995) ja relationaalisen käänteen (Edwards 2010; 2017; Duhn ym. 2016; Sannino \& Engeström 2017) näkökulmaa, jossa korostetaan asiantuntijuuden kollektiivista, avointa luonnetta. Tuon esille asiantuntijuuden ja jaetun asiantuntijuuden määritelmiä ensin yleisellä tasolla, minkä jälkeen esittelen tarkemmin, mitä tässä tutkimuksessa tarkoitan asiantuntijuudella ja sen jakamisella.

Suomenkielinen termi asiantuntija viittaa tietämiseen: asiantuntija tietää ja tuntee asiansa (Tynjälä 2004, 176). Englanninkielinen expert puolestaan liitetään kansainvälisessä tutkimuskirjallisuudessa tietämisen lisäksi osaamiseen, tekemiseen ja käytäntöön (Collin 
Opettajan asiantuntijuus muutoksessa - asiantuntijuus ja sen jakamisen diskurssit digitaalisessa oppimisympäristössä

2010; Tynjälä 2004). Asiantuntijaa määrittelee hänen kykynsä lisätä tietouttaan kokemuksista oppien ja näin saavuttaa suvereenius omalla asiantuntijuusalueellaan (Parviainen 2006; Eräsaari 2002). Suomalaisessa tutkimuskirjallisuudessa ja sosiologisessa professiotutkimuksessa on asiantuntijuus perinteisesti määritelty kuuluvaksi tieteeseen, instituutioihin ja tiukkarajaisten professioiden maailmaan (Eräsaari 2002; Saaristo 2000, 31). Yksilöasiantuntijuus, suljettu asiantuntijuus (Eräsaari 2002, 21-22; Parton 2002, 238), on korostunut. Tällainen moderneille yhteiskunnille tyypillinen profession määritelmä on KarvinenNiinikosken mukaan $(2009,132)$ pysynyt pitkään muuttumattomana, eikä siihen kuuluvassa asiantuntijuuden määritelmässä ole ollut maallikoille mitään sijaa.

Asiantuntijuuden kehittyminen nähtiin vielä 1990-luvun alkupuolella yksilöön sidottuna, mutta 1990-luvun jälkipuolelta lähtien on tutkimus painottunut asiantuntijuuteen yhteisöllisenä prosessina ja asiantuntijuuden jakamiseen (Eräsaari 2002, 21-22; Parton 2002, 238). Asiantuntijuutta voi tarkastella monesta eri näkökulmasta, ja tässä tutkimuksessa painotan jaetun asiantuntijuuden näkökulmaa. Tarkastelun kohteena on asiantuntijuuden diskursiivinen jakaminen verkkoympäristössä yliopistolla työskentelevien opettajien ja opiskelijoiden haastattelupuheessa. Määrittelen jaettua asiantuntijuutta (shared expertise) asiantuntijan ja noviisin hierarkkisen jaon avulla. Tarkastelen, miten puheessa jaetaan opettajan professioon liittyvää asiantuntijuutta ja noviisien eli opiskelijoiden käytännön tietoa ja kokemusta. Suomennettuna "jakaminen" (sharing) kuulostaa erottamiselta (Pärnä 2012). Jakamisella tarkoitan tässä tutkimuksessa uuden tiedon synnyttämistä ja yhteistä osaamista, kuten muun muassa D'Amour (2005), Parviainen (2006), Edwards (2010; 2017) ja Koskela (2013), jotka sanovat jaetun tiedon ja osaamisen olevan enemmän kuin opettajat ja opiskelijat yksilöinä pystyisivät tuottamaan. Parviaista (2006) ja Edwardsia (2010; 2017) mukaillen tarkoitan jaetulla asiantuntijuudella toimijoiden kollektiivista tiedonrakentamista, joka toteutuu hierarkkisesta asetelmasta huolimatta. Koen opettajien ja opiskelijoiden toiminnan olevan tavoitteellista, tietoista yhdessä osaamista, jota määrittelee yhteinen päämäärä. Oleellista on taito oppia toisilta ja tiedon vastavuoroinen jakaminen toinen toiselle.

Jaetun asiantuntijuuden käsitettä voi lähestyä myös vastakkainasettelun kautta. Silloin jaettu asiantuntijuus nähdään suljetun asiantuntijuuden vastakohtana. Suljettu asiantuntijuus korostaa asiantuntijan ja ei-asiantuntijan välistä hierarkkista valta-asemaa ja epätasaarvoista suhdetta. Jaettu asiantuntijuus nähdään avoimena, hierarkiat poistavana asiantuntijuutena, jolloin kuka tahansa, myös perinteiseen professioon kuulumaton, voi olla asiantuntija. (Raitakari 2002, 48-51.) Osaamisen jakaminen tuo yksilöasiantuntijuuden rinnalle toisenlaisen asiantuntijuuden, jossa korostuu tiedon kollektiivisuus. Yhteisöllisessä eli kollaboratiivisessa oppimisessa, jota tapahtuu asiantuntijoiden vuorovaikutuksessa, oleellista on yhteinen ymmärrys ja todellisuus. Yhteistä uutta tietoa tuotetaan toimimalla yhdessä. Tärkeää on, että osallistujat tietävät yhteisen tavoitteen ja ovat osallistuneet sen määrittelyyn. (Leinonen ym. 2006, 141-144; Pärnä, 2012, 42.)

Yhdessä toimiminen ja rajoja ylittävä työ suuntaavat painopisteen asiantuntijakeskeisyydestä asiantuntijoiden vuoropuheluksi. Rajojen ylittämisestä ja rajatyöstä kirjoittaa muun muassa Anne Edwards (2010; 2017). Toimijoiden aloittaessa yhteisen työskentelyn syntyy aina uusi yhteistyötila (boundary space), jossa rajatyötä ja rajan ylittämistä tehdään ja jossa yhteinen osaaminen ja tieto syntyvät. Edwardsin (2017) mukaan keskeisintä ei ole rajojen sulauttaminen vaan rajapintatilojen luominen ja työskentely niissä. Menestyksellinen rajoilla työskentely edellyttää tietoista työtä niiden ylittämiseksi (Edwards 2010). Tässä tutkimuksessa näen digitaalisen oppimisympäristön rajatilana, jossa asiantuntijuutta jaetaan ja yhdistetään ja jossa rajojen ylittäminen tapahtuu. 


\section{Tutkimuksen tavoitteet ja aineiston esittely}

Kysyn tutkimuksessani, miten asiantuntijuutta tuotetaan erilaisten puhetapojen avulla ja miten asiantuntijuutta jaetaan, kun sosiaalityöntekijäopiskelijoiden kandidaatintyön ohjaus tapahtuu verkon välityksellä. Tutkimusaineistonani oli kandidaatintutkielmaseminaaria verkkovälitteisesti (Adobe Connect -ohjelman avulla) suorittaneiden sosiaalityöntekijäopiskelijoiden $(\mathrm{N}=8)$ ja heidän opettajiensa $(\mathrm{N}=4)$ haastattelupuhe. Tutkimuspaikkanani olevassa yliopistossa hyödynnettiin Adobe Connect -ohjelmaa kandidaatintutkielmaseminaarin toteutuksessa ensimmäistä kertaa. Kandidaatintutkielmaseminaariryhmän verkkokokoontumiset ja ryhmän työskentelyn sisältö vastasivat perinteisen, kasvokkaisen seminaarityöskentelyn sisältöjä ja tavoitteita. Kandidaatintutkielmaseminaariryhmä muodostui yhden vuosikurssin opiskelijoista $(\mathrm{N}=16)$, jotka oli jaettu kolmeen verkkoryhmään, ja jokaista ryhmää ohjasi yksi opettaja. Opiskelijoilla oli verkossa tapahtuvien ryhmätapaamisten lisäksi mahdollisuus henkilökohtaiseen ohjaukseen Skype-ohjelman välityksellä. Keräsin haastatteluaineistoni yliopistolla vireillä olleen laajemman kehittämistutkimuksen puitteissa, jonka tavoitteena oli kehittää uusia verkko-opiskeluteknologioihin painottuvia ratkaisuja ja edistää yliopisto-opintojen monimuotoisuutta. Otin yhteyttä kurssin opettajiin sopiakseni haastatteluista ja lähestyin kaikkia seminaariryhmän opiskelijoita sähköpostitse haas tattelukutsulla. Haastatteluissani oli opiskelijaedustus kaikista kolmesta verkkoryhmästä. Kaikki opiskelijahaastattelut yhtä lukuun ottamatta toteutin Skype-yhteyden välityksellä, sillä opiskelijat asuivat eri puolilla Suomea. Yhden opiskelijan haastattelin yliopistolla erillisessä tilassa. Opettajat haastattelin joko opettajan työhuoneessa tai haastattelua varten varaamassani tilassa. Haastattelujen kesto vaihteli 40 minuutista 75 minuuttiin. Jokaista haastateltavaa haastattelin yhden kerran. Nauhoitin haastattelut ja ne litteroitiin. Haastateltavia opettajia oli lopuksi neljä, sillä erään ryhmän opettaja vaihtui toiseen kesken seminaarikurssin. Haastateltavat olivat tietoisia haastattelujen hyödyntämisestä tutkimuksessani.

\section{Tutkimuksen metodologia}

Tutkimustani ohjaavana tausta-ajatuksena olen hyödyntänyt sosiaalista konstruktionismia, jossa tiedon ja käsitteiden ajatellaan rakentuvan sosiaalisesti ihmisten kielellisessä vuorovaikutuksessa ja toiminnassa (Berger \& Luckmann 1994; Gergen 1994). Viitekehyksen valinta aktualisoituu tutkimuskohteeni, tutkimuskysymysteni, analyysitapani sekä tutkimustulosteni sosiaalisen todellisuuden kuvaamisen ja luomisen kautta. Aineistonkeruumenetelmäksi valitsin puolistrukturoidun teemahaastattelun, jotta pääsisin syvälle haastateltavien omiin asiantuntijuutta ja sen jakamista koskeviin tulkintoihin ja merkityksenantoihin. Koska tutkimukseni oli osa yliopistolla toteutettavaa laajempaa kehittämistutkimusta, sisälsivät haastatteluni myös laajempaan kokonaisuuteen liittyviä teemoja (ks. puolistrukturoitu teemahaastattelurunko liitteenä). Haastatteluissa keskustelimme verkkoseminaarityöskentelyn toteutuksesta, oppimisen tukemisesta ja seminaarityön ohjauksesta, vuorovaikutuksesta, dialogista sekä asiantuntijuudesta. Tässä tutkimuksessa analysoin kaikkea keräämääni haastatteluaineistoa. Haastattelukysymysten työstämisvaiheessa määrittelin analyysiyksiköiksi kolme toisiaan täydentävää asiantuntijuuden osa-aluetta: tieteellinen, teknologinen ja sisällöllinen. Asiantuntijuuden kolmijako perustuu sosiaalityön profession erityisyyteen (ks. esim. Patrikainen 2000), opettajan asiantuntijuuden osa-alueisiin (Tynjälä 2004; Korhonen \& Koivisto 2007), omaan työ- ja koulutuskokemukseeni sekä aiempiin asiantuntijuuden ja professionaalisen oppimisen tutkimuksiin (ks. esim. Vuorikoski \& Räisänen 2010, Eräsaari 2002) ja teorioihin asiantuntijuudesta ja teknologian käytöstä opetustyössä (ks. esim. Tynjälä 2006; Korhonen \& Koivisto 2007). 
Edellä mainittujen tutkimusten perusteella määrittelin teknologisen asiantuntijuuden sisältämään teknologiaan, sen osaamiseen ja hallintaan liittyviä asioita, sisällöllisen asiantuntijuuden tarkoittamaan sosiaalityön substanssiosaamista ja tieteellisen asiantuntijuuden liittymään tieteen tekemiseen, tieteenteorioihin ja tutkimustyöhön. Tämän jaottelun tarkoituksena ei ole asettaa näitä asiantuntijuuden osa-alueita keskenään kilpaileviksi tai vastakkaisiksi. Ennemmin kuin toisiaan poissulkevina alueet tulee nähdä toisiaan täydentävinä ja yhteen kietoutuneina.

Tein tulkintoja haastatteluaineistosta hyödyntäen sisällön analyysia (Tuomi ym. 2002) ja diskurssianalyysia (Fairclough 1992; Jokinen ym. 2016). Sisällön analyysia hyödynsin analyysivaiheen alussa tutustuttuani ensin huolellisesti litteroituun aineistoon. Sisältöanalyysin avulla luokittelin aineistoa poimimalla teksteistä kohdat, joissa haastateltavat kuvaavat tulkintojaan asiantuntijuudestaan ja sen kolmesta osa-alueesta. Tarkastelin myös, esiintyykö aineistossa jaottelemieni asiantuntijuuden osa-alueiden lisäksi muita asiantuntijuuteen liitettäviä osa-alueita. Luokittelu auttoi diskurssien määrittelyssä, sillä se selkeytti aineistosta muodostunutta kuvaa. Tämän jälkeen kiinnitin diskurssianalyysia soveltaen huomioni itse teksteihin ja niiden sisällä erityisesti lausumiin ja puhetapoihin, jotka viittasivat asiantuntijuuteen, johonkin asiantuntijuuden kolmesta osa-alueesta tai asiantuntijuuden jakamiseen. Analyysini oli aineistolähtöinen enkä liittänyt siihen ennakko-oletuksia esimerkiksi diskurssien valtasuhteista. Sen sijaan konstruktiivinen tutkimusotteeni (ks. Berger \& Luckman 1994; Gergen 1994), johdatti huomioni sosiaalisen todellisuuden rakentumisen prosesseihin (Jokinen ym. 2016) eli siihen, miten asiantuntijuutta tuotetaan ja millaisten diskurssien kautta sitä jaetaan.

Poimimistani puhetavoista muodostin diskurssianalyysia soveltaen yhtenäisiä tapoja puhua asiantuntijuudesta ja sen jakamisesta. Ryhmittelin puhetavat neljäksi eri diskurssiksi. Jos puhetapa esiintyi heikkona, esimerkiksi kerran tai kaksi, en muodostanut siitä omaa diskurssia. Muodostin diskurssin, jos puhetavalla oli keskeinen rooli asiantuntijuuden osaalueiden tuottamisessa tai jakamisessa. Muodostin diskursseja myös tekstissä esiintyvien diskurssien keskisten valtataisteluiden (Jokinen ym. 2016) vuoksi. Mainitulla diskurssilla oli tällöin vaikutuksia muihin diskursseihin ja näiden välisiin suhteisiin. Parker (1992) kuvaakin, miten diskurssit ovat usein monin tavoin kietoutuneet yhteen ja niiden keskinäiset suhteet monimutkaisia. Niiden rajat eivät myöskään ole aina itsestään selviä vaan osin tutkijan harkinnan varassa. Tuon tutkimuksen tulososiossa suorien aineistolainauksien avulla esille, miten diskurssit joskus esiintyivät puhujan lauseissa sopuisasti peräkkäin samanarvoisina puhetekoina, kun taas joskus toiset diskurssit ottivat valta-asemaa suhteessa muihin.

\section{Asiantuntijuusalueilla esiintyvät diskurssit}

Muodostin aineistosta edellä kuvaamani analyysitavan mukaisesti neljä eri puhetapaa (ks. Kuvio 1.). Tutkimukseen osallistuneiden haastateltavien yksityisyyden suojaamiseksi käytän aineistolainauksen perässä vain nimimerkkiä "opiskelija" tai "opettaja". Lisäsin tunnistetiedon, esimerkiksi "opettaja 1" tai "opiskelija 3", jotta lukijalle muodostuu selkeämpi kuva tutkimuksessa käytettyjen suorien aineistolainauksien laajuudesta. Seuraavaksi esittelen lyhyesti asiantuntijuuden osa-alueet kuvaten ensin, miten opettajat ja opiskelijat määrittelivät kutakin asiantuntijuuden osa-aluetta ja miten he puheessaan rakensivat teknologista, sisällöllistä ja tieteellistä asiantuntijuutta. Tämän jälkeen tuon tarkemmin esiin aineistosta muodostamani diskurssit sekä niitä havainnollistavat määritelmät ja aineistolainaukset. 


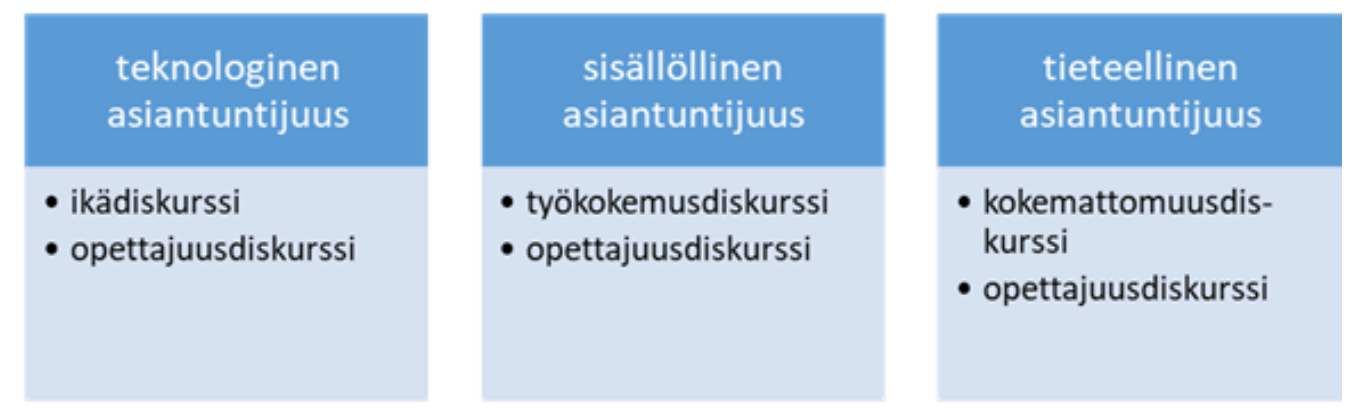

Kuvio 1. Asiantuntijuuden kolme sisältöaluetta, joita tuotetaan eri diskurssien kautta.

\section{Teknologinen asiantuntijuus}

Opettajat ja opiskelijat toivat esiin, että teknologinen asiantuntija on henkilö, joka toimii luontevasti teknologian parissa. Teknologinen asiantuntija pystyy ratkaisemaan teknologiaan liittyviä ongelmia, on valmis jakamaan tietämystään muille sekä kannustaa ja auttaa muita. Teknologista asiantuntijuutta tuotettiin puheessa ikädiskurssiksi ja opettajuusdiskurssiksi nimeämieni puhetapojen kautta. Alla oleva esimerkki havainnollistaa, millainen henkilö on teknologinen asiantuntija.

No mä voisin sanoo, et meil oli näit tämmösii sessioita, et kyllä siellä välillä oli teknologisessa asiantuntijuudessa semmosia ihmisiä, jotka tiesi jostain asiasta ja pysty neuvomaan enemmän, et siinäkin tuli semmosta tasavertasuutta. Sitten myös opiskelijat oppi käyttämään sitä chat- työkalua, elikkä niin et jos he halus jollekin jonkun lähteen etsiä, ni he etsi toisilleen, hyvin näppärästi liittivät copy-paste siihen chattiin, ja sitten oli sitä, et tavallaan siinä opiskelijat otti aika aktiivista roolia siinä asiantuntijuudessa ja oli valmiita jakamaan siit omastansa ja sit myös kannustamaan toisiaan. (Opettaja 3.)

\section{1) Ikädiskurssi}

Teknologista asiantuntijuutta tuotettiin vahvasti ikäpuheella. Teknologian nähtiin olevan nuorten opiskelijoiden ja opettajien osaamis- ja vahvuusaluetta. Ikädiskurssissa, jota opettajat ja opiskelijat tuottivat, korostettiin nuorten luontaista toimimista teknologian parissa ja vanhempien henkilöiden teknologista osaamattomuutta ja tietämättömyyttä. Puhetavalle oli ominaista, että jaottelua nuoriin ja vanhempiin ei kyseenalaistettu. Asiantuntijuutta tuotettiin eronteon kautta, "meikäläisen ikäiset", erotuksena nuorista.

Ja varmaan opiskelijasta riippuen nää on myös tämmösii sukupolvikysymyksiä myöskin että, on joitakin nuoria, joille se on hyvin luontevaa ja näin ja sit on jotakin meikäläisen ikäisiä tai jopa vanhempia, jotka sitten on varovaisempia sen kanssa. (Opettaja 4.)

\section{2) Opettajuusdiskurssi}

Opettajuusdiskurssi näyttäytyi aineistossa teknologiseen, sisällölliseen ja tieteelliseen asiantuntijuuteen liittyvänä puhetapana. Opettajuusdiskurssiksi nimesin puhetavan, jossa opiskelijat ja opettajat liittivät opettajuuteen ja opettajana toimimiseen tiettyjä ominaisuuksia itsestään selvästi, kyseenalaistamatta. Nämä olivat ominaisuuksia ja piirteitä, joita opettajilla yleisesti ajatellaan olevan. Opiskelijat, jotka tuottivat puhetapaa selvästi enemmän 
Opettajan asiantuntijuus muutoksessa - asiantuntijuus ja sen jakamisen diskurssit digitaalisessa oppimisympäristössä

kuin opettajat, he toivat esiin, että lähtökohtaisesti opettajilta edellytetään monien asiantuntijuuden osa-alueiden hallintaa.

Mutta tietysti sit semmosis tilanteis, ku on paljon teknisii ongelmii, joit opettajatkaan ei osaa korjata ja fiksata, ja jopa hekin ihmettelee, mikä tässä on nii... (Opiskelija 2.)

Puhetavasta käy ilmi, että käytännössä eteen voi tulla tilanteita, joita opettajatkaan eivät osaa ratkaista. Lainaus sisältää latautuneen odotuksen niistä taidoista, joita opettajilla oletetaan olevan.

Kyl mun mielest [teknologinen]asiantuntijuus niin oli siellä opettajalla nimenomaan. Tottakai opiskelijoilta sitte kans semmosta vertaisohjausta ja muuta, mutta kyl se asiantuntijuus täytyy olla siellä opettajalla. (Opiskelija 8.)

Korostaessaan "kyl se asiantuntijuus täytyy olla siellä opettajalla" puhuja toi esille, että opiskelijoiden pitäisi ongelmien ilmaantuessa pystyä luottamaan opettajiin ongelmien ratkaisijoina. Puhuja ei ottanut vastuuta mahdollisten teknisten ongelmien ratkaisemisesta, vaan eriytti roolinsa opettajista tuottaen itse itselleen oikeutuksen olla tietämättä ja osaamatta. Tämä oikeutus liittyi tiiviisti opettajan ja opiskelijan roolijakoon. Opiskelijoiden tuottaessa opettajuusdiskurssia vallalla olivat itsestäänselvyydet ja kyseenalaistamattomuudet. Opettajuusdiskurssi sai haastajan työkokemusdiskurssista, jota esittelen myöhemmin.

Opettajien tuottaessa opettajuusdiskurssia puhe ja siihen sisältyvät odotukset kohdistuivat heihin itseensä henkilökohtaisesti, ei opettajiin yleisellä tasolla. Opettajat tuottivat opettajuusdiskurssia omista positioistaan, jolloin diskurssi oli heille myös väline, jolla rakentaa ammatti-identiteettiä. Diskurssi sisälsi tavoitteen olla hyvä, osaava opettaja. Ellei saavuttanut tavoitettaan, opettaja pettyi ja soimasi itseään:

... ja sit tulee ihan semmonen paniikki, et no hitto enks mä osaa tätä, ei täst tuu mitään ja olispa, voi kun me oltais täällä kaikki kasvotusten. (Opettaja 4.)

\section{Sisällöllinen asiantuntijuus}

Sisällöllinen asiantuntijuus tarkoitti haastateltujen puheessa substanssiosaamista, sosiaalityön sisältöalueiden tietämystä, niin teoreettista kuin käytännöllistäkin, sekä työ- ja elämänkokemuksen mukanaan tuomaa asiantuntijuutta. Sisällöllinen asiantuntijuus kuvattiin melko kapea-alaiseksi, mutta sitäkin syvemmäksi oman alan tietämykseksi. Sisällölliseen asiantuntijuuteen liittyvää puhetta tuottivat sekä opettajat että opiskelijat, ja sitä konstruoitiin edellä esittelemäni opettajuusdiskurssin ja työkokemusdiskurssin kautta. Opettajuusdiskurssia tuottaessaan opiskelijat edellyttivät itsestään selvästi, että opettajalla tulisi olla sosiaalityön sisällöllistä asiantuntijuutta.

- No ensinnäkin se, et se opettaja on sen alan, mitä ne opiskelijat opiskelee, niin sen alan asiantuntija.

- Pitäisi olla vai?

- Niin mun mielestä pitäis olla. Niin, et tietää mist opiskelijat puhuu sitte, ja mitä ne siihen työhön ottaa. (Opiskelija 2.) 
3) Työkokemusdiskurssi

Työkokemusdiskurssiksi nimesin puhetavan, jonka kautta opiskelijatkin pääsivät osalliseksi sisällöllisestä asiantuntijuudesta. Työkokemusdiskurssia tuottivat niin opettajat kuin opiskelijatkin. Opiskelijat olivat työnsä kautta saaneet kokemusta sosiaalityöstä, ja tämä avasi heille väylän sisällölliseen asiantuntijuuteen. Se ei toki yksinään riittänyt, mutta työ- ja elämänkokemuksen yhdistelmä mahdollisti opiskelijoille pääsyn sisällölliseen asiantuntijuuteen:

No heil on se tieteellinen, teoreettinen ja sit taas määki, ku mä oon käytännön työtä tehny täs ny 15 vuotta, niin meil on taas se tämän hetken ehkä se käytännön tieto. Et sit ne käy ehkä semmost vähä vuoropuheluu, et on tää tieteellinen ja sit on se käytännön sosiaalityön, niin ne jotenki sillai muokkautuu siinä. Niin mä aattelisin, et olisko se sit aika semmost tasavertastaki, et se olis semmost dialogistakin. Et kyl sit, ko siel joku opettaja jotaki sanoo, niin sit vähä sillai kyseenalaistaakin, et jaa no, onkohan se ny, ei se ny käytännös ihan tollai oo... (Opiskelija 2.)

Esimerkissä viitataan ensin opettajuusdiskurssin kautta opettajien tieteelliseen, teoreettiseen tietoon ja osaamiseen. Tämän jälkeen puhuja tuo työkokemusdiskurssia käyttäen esille, että on tehnyt sosiaalityötä 15 vuotta, joten on saavuttanut käytännön tietotaidon ja osaamisen työnsä kautta. Työkokemusdiskurssi haastaa opettajuusdiskurssin ja hakee sen avulla pääsyä sisällölliseen asiantuntijuuteen. Asiantuntijuutta ja sen kehittymistä määrittävätkin Valkeavaaran (2005) mukaan formaalin koulutuksen lisäksi vahvasti erilaiset työkokemukset ja työssä oppiminen. Puhetapaa käyttänyt opiskelija kuvasi, että asiantuntijuus oli "aika semmost tasavertastaki", mikä kavensi opettajan ja opiskelijan välistä eroa, ja lopussa puhuja uskalsi jopa kyseenalaistaa opettajan sisällöllistä asiantuntijuutta.

\section{Tieteellinen asiantuntijuus}

Tieteellinen asiantuntijuus oli opettajien ja opiskelijoiden mielestä spesifiä ja kapea-alaista asiantuntijuutta, joka liitettiin tieteellisen tutkimustyön ja erilaisten tieteellisten teorioiden hallintaan. Tieteellistä asiantuntijuutta tuotettiin kokemattomuusdiskurssiksi ja opettajuusdiskurssiksi nimeämieni puhetapojen kautta. Opettajuusdiskurssi esiintyi hallitsevana tieteellisessä asiantuntijuudessa ja lähes poikkeuksetta tämä asiantuntijuuden osa-alue liitettiin vain opettajan asiantuntijuuteen kuuluvaksi. Tieteellinen asiantuntijuus voidaan saavuttaa pitkäjänteisen tieteellisen tutkimustyön kautta. Tästä asiantuntijuuden osa-alueesta opiskelijat eivät tuntuneet haluavan olla osallisina, niin itsestään selvästi se liitettiin opettajuu teen. Seuraavassa esittelen tieteelliseen asiantuntijuuteen liittyvän, opettajan tuottaman puhetavan, joka korosti opettajan ehdotonta roolia tutkimusprosessien asiantuntijana.

Se sit taas, et mikä mun rooli opettajana oli, tietysti se tutkimuksen prosessi ja ne finessit, mitkä siel on oltava, jotta siitä tulee akateemisesti hyväksyttävä opinnäyte, ni osaaminen toki on siellä opettajan hanskassa. (Opettaja 2.)

4) Kokemattomuusdiskurssi

Kokemattomuusdiskurssiksi nimesin puhetavan, jolla korostettiin henkilön kokemattomuutta suhteessa työhön, tieteelliseen tutkimukseen ja elämänkokemukseen. Kokemattomuusdiskurssi kohdistui vain opiskelijoihin ja ainoastaan opiskelijat tuottivat sitä. Tämän puhetavan avulla he toivat esiin, että eivät olleet aiemmin tehneet tieteellistä tutkimusta, joten he eivät kokeneet itsellään olevan tieteellistä asiantuntijuutta. Kandidaattityövaihees- 
Opettajan asiantuntijuus muutoksessa - asiantuntijuus ja sen jakamisen diskurssit digitaalisessa oppimisympäristössä

sa olevien opiskelijoiden tieteellinen kokemattomuus oli yleisesti tiedossa oleva, hyväksytty asia, eivätkä tätä tulkintaa horjuttaneet mitkään vaihtoehtoiset diskurssit. Kokemattomuusdiskurssin yhteydessä esiintyi usein tieteellistä asiantuntijuutta konstruoiva opettajuusdiskurssi:

\begin{abstract}
Meil ei ollu kokemusta tieteellisen tutkimuksen tekemisestä esimerkiks. Me oltii iha sillai vihreitä, se oli ihan uutta. Nii kyl se opettaja tietysti, hän on väitöskirjan tehny ja näin, nii aika paljon tutkinu sitte jo monennäköstä siihen mennessä. Tottakai hänel on jo tämmösen kokemuksen ja osaamisen kautta aivan erilainen lähtökohta siihen. Ja sit mietin, jos me oltais oltu erityyppinen ryhmä, et mukana olis ollu esimerkiks opiskelija, jolla on sit jo paljon kokemusta, nii hän ois varmasti eri tavalla osannut sitten jo kommentoida meiän papereita. Nyt me oltiin hyvin sillai samantyyppinen ryhmä sen suhteen. Meillä oli kaikilla kovin vähän kokemusta tutkimuksen tekemisestä. (Opiskelija 7.)
\end{abstract}

Puhuja käytti ensin kokemattomuusdiskurssia kertoen, että "ei ollut kokemusta tieteellisen tutkimuksen tekemisestä.” Tämän jälkeen hän jatkoi tieteellisen asiantuntijan määrittelyä opettajuusdiskurssin avulla kertoen opettajan täyttävän tieteellisen asiantuntijan määritelmän, sillä hän on väitöskirjan lisäksi tehnyt paljon tutkimusta. Puhuja viittasi lopuksi siihen, että jos ryhmässä olisi ollut mukana tieteellistä tutkimusta tehnyt opiskelija, niin hän olisi voinut tuoda asiantuntijuuttaan kommenttiensa avulla esille. Puhuja liikkui kokemattomuus- ja kokemussektoreilla määritellessään tieteellistä asiantuntijuutta.

\title{
Asiantuntijuuden jakaminen diskursseissa
}

Tarkastelin yliopistolla työskentelevien opettajien ja opiskelijoiden haastattelupuheesta, miten asiantuntijuutta tuotettiin eri puhetavoilla ja miten asiantuntijuutta jaettiin. Teknologista asiantuntijuutta jaettiin puhetavoissa tasaisesti: "kuka siellä nyt silloin paremmin osas."

\begin{abstract}
Riippuu opettajasta [naurahdus]. Se ehkä enemmän sit meni sil taval, et kuka nyt osas sitä ohjelmaa parhaiten käyttää tai oli ratkassu sen ongelman jo ennen nii sit osas tuoda siihen keskusteluun, et hei kokeilepa nyt ja katsopa sieltä. Ja siinä ehkä se oli huomattavasti tasapuolisempaa ja se jakautu tasaisemmin [asiantuntijuus]. Eli ne kenellä oli enemmän tietoa, nii jakoi sitä sitte muille. (Opiskelija 7.)
\end{abstract}

Teknologisessa asiantuntijuudessa tehtiin rajoja ylittävää käytännönläheistä yhteistyötä (Edwards 2010; 2017) ja luotiin yhdessä uudenlaista asiantuntijuutta ja osaamista. Tämä kyseenalaisti perinteistä opettajien ja opiskelijoiden välistä työnjakoa. Parhaiten teknologiaa hallitseva saattoi olla yhtä hyvin opettaja kuin opiskelijakin. Ikä eli nuorempana tai vanhempana ihmisenä oleminen jaotteli teknologista asiantuntijuutta vahvemmin kuin jako opettajiin ja opiskelijoihin. Opettajuusdiskurssi piti yllä opettajuuteen liittyvää teknologian hallitsemisen vaadetta, ikädiskurssin tullessa haastamaan ja jakamaan tätä opettajuuteen itsestään selvänä liitettyä asiantuntijuuden osa-aluetta. Opettajat toivat useasti esille, että heillä oli opiskelijoiden kanssa samat lähtökohdat teknologian käyttämiselle. Esiintyi eräänlaista me-henkeä, ja opettajat ja opiskelijat toimivat yhdessä opetellen teknologian käyttöä ja neuvoen toinen toistaan. Edwardsin mukaan (2010) yhteisen ongelman ratkaise- 
miseksi ja uuden tiedon luomiseksi ovat keskeisiä tahto ja kyky oppia toisilta ja oman osaamisen jakaminen. Puhetavoissa tuli vahvasti esiin yhdessä tekeminen ja oivaltaminen.

Myös sisällöllistä asiantuntijuutta jaettiin diskursseissa opettajien ja opiskelijoiden kesken. Opettajuusdiskurssi piti vahvasti yllä käsitystä, että sisällöllinen asiantuntijuus kuuluu opettajuuteen itsestään selvänä. Työkokemusdiskurssi kyseenalaisti opettajuusdiskurssin valta-asemaa ja jakoi sisällöllistä asiantuntijuutta hierarkkisesta asetelmasta huolimatta (Parviainen 2006; Edwards 2010; 2017) myös opiskelijoille. Oleellista sisällöllisen asiantuntijuuden jakamisen mahdollistamisessa oli opettajien rooli ja asenne, kuten seuraavasta aineistoesimerkistä käy ilmi.

\section{Kyl mun mielest varmaan yks on se, että sitä, et opettajana ei ajattele sitä rooliansa niin, että minä olen tässä nyt se, joka kaiken tietää ja minä teille täältä nyt sylkäsen, et kuinka tää homma toimii, ikään ku opettajana ymmär- tää sen, että itsellä on todella paljon oppimista niiltä opiskelijoilta ja nää on opiskelijoita, joilla on työkokemusta ja niillä on opiskelukokemusta ja niillä on elämänkokemusta ja kaikenlaista kokemusta, jota he sitten hyvin auliisti- kin jakavat. (Opettaja 3.)}

Opettaja pienensi ensin omaa rooliaan taka-alalle, minkä jälkeen hän asetti itsensä myös oppijan asemaan (vrt. Pelttari ym. 2017). Lopuksi opettaja käytti työkokemusdiskurssia korostaakseen opiskelijoiden sisällöllistä asiantuntijuutta. Opiskelijatkin toivat esiin, miten oli "hauskakin huomata", että opettaja ei voi tietää kaikkea sosiaalityöstä ja opettajakin voi toisinaan olla oppijan roolissa. Sisällöllisen asiantuntijuuden jakamisessa tuli esiin toimijoiden vastavuoroinen resurssien hyödyntäminen (ks. esim. Pärnä 2012) ja osaamisten yhdis täminen (Edwards 2010).

Edellä esittelemistäni asiantuntijuuden osa-alueista poiketen ei tieteellistä asiantuntijuutta puhetavoissa jaettu. Tieteellinen asiantuntijuus, jota tuotettiin opettajuus- ja kokemattomuusdiskurssin kautta, pysyi yksinomaan opettajien hallussa. Näitä diskursseja eivät tulleet haastamaan muut diskurssit, jotka olisivat vaatineet tieteellisen asiantuntijuuden jakamista. Tieteellinen asiantuntijuus nähtiin vahvasti opettajaan, opettajuuteen ja pitkälliseen tutkimustyöhön liittyväksi. Opiskelija kuvasi, että "se menetelmäosaaminen ja se, niin se tulee sieltä, opettajalta" ja opettaja tarkensi, että "tietysti se tutkimuksen prosessi ja ne finessit, mitkä siel on oltava, ni osaaminen toki on siellä opettajan hanskassa". Tästä asiantuntijuuden osa-alueesta opiskelijat eivät näyttäneet diskursseissa haluavan osalliseksi tai se miellettiin niin itsestään selvästi vain akateemiseen professioon kuuluvaksi, että sitä ei edes lähdetty tavoittelemaan.

\section{Yhteenveto ja pohdinta}

Tutkimukseni tavoitteena on osallistua keskusteluun opettajan profession muutoksesta ja analysoida, miten asiantuntijuutta tuotetaan ja jaetaan yliopistolla työskentelevien opettajien ja opiskelijoiden haastattelupuheessa. Tutkimukseni osoittaa, että käsitteenä asiantuntijuutta kuvataan opettajien ja opiskelijoiden puheessa yhtenäisesti ja sitä tuotetaan neljän eri puhetavan kautta: ikädiskurssin, opettajuusdiskurssin, työkokemusdiskurssin ja kokemattomuusdiskurssin. Teknologista, sisällöllistä ja tieteellistä asiantuntijuutta jaetaan diskursseissa eri tavoin. Opiskelijan teknologinen ja sisällöllinen asiantuntijuus haastaa ja jakaa opettajan asiantuntijuutta eri diskursseissa. Tieteellinen asiantuntijuus ei tule diskursseissa haastetuksi, minkä vuoksi se jää ainoastaan opettajille kuuluvaksi asiantuntijuuden osa-alueeksi. 
Teknologista asiantuntijuutta tuotettiin ikä- ja opettajuusdiskurssin kautta ja sitä jaettiin tasapuolisesti opettajien ja opiskelijoiden kesken. Teknologisen asiantuntijuuden jakamista ikädiskurssin kautta selittivät nuorten opettajien ja opiskelijoiden teknologiset taidot. Ikädiskurssi oli teknologisessa asiantuntijuudessa hallitsevana eli ikä vaikutti haastateltavien puheessa näkemykseen teknologian osaamisesta ja hallinnasta enemmän kuin opettajuusdiskurssin kautta opettajana toimimiseen liitetyt muut ominaisuudet. Tämä on mielenkiintoista, sillä Suomessa opetusteknologian käyttö on tutkimusten mukaan jatkuvassa kasvussa, ja se on varsin opettajajohtoista (Murtonen 2017; Kivimäki 2006). Tutkimustulosteni mukaan teknologisen asiantuntijan roolia ei ollut kovin vaikeaa saavuttaa, vaan siihen riitti tietokoneen peruskäytön hallinta sekä halu auttaa ja neuvoa toisia. Haastattelemani opettajat kokivat helpotusta teknologisen asiantuntijuuden jakautuessa opettajien ja opiskelijoiden kesken, mikä tukee aikaisempaa teknologiavälitteistä jaetun asiantuntijuuden tutkimusta (Conole 2013; Pelttari ym. 2017). Toisaalta tutkimuksessani teknologisen asiantuntijuuden jakaminen opettajilta opiskelijoille ei sujunut aina ilman kipua. Toiset opettajat soimasivat itseään, kun eivät hallinneetkaan teknologiaa.

Sisällöllistä asiantuntijuutta tuotettiin työkokemus- ja opettajuusdiskurssin kautta. Opettajuusdiskurssi piti sisällöllistä asiantuntijuutta opettajuuteen itsestään selvästi liittyvänä osa-alueena. Työkokemusdiskurssin avulla opiskelijat pääsivät osalliseksi sisällöllisestä asiantuntijuudesta ja sen tuomalla varmuudella he uskalsivat jopa kyseenalaistaa opettajien asiantuntijuutta. Sisällöllisen asiantuntijuuden jakamista selittää osaltaan tutkimusaineiston tuottanut aikuisopiskelijaryhmä. Vuorikosken ja Törmän (2007) mukaan juuri aikuisopiskelijat pyrkivät helposti haastamaan opettajan substanssiosaamisen. Tulokseni on yhtenevä aiemman tutkimuksen kanssa (ks. Vaherva 2005; Vuorikoski \& Törmä 2007; Tynjälä 2004), jonka mukaan asiantuntijuutta voi syntyä ilman formaalia koulutusta opiskelun ja työelämän tiiviissä vuorovaikutuksessa. Näin ollen koulutukseen perustuvaa, ammatti- ja reviirihierarkiaan pohjautuvaa asiantuntijuutta voidaankin pitää yhä keinotekoisempana ja työelämän kannalta merkityksettömämpänä (Launis \& Engeström 2005 [1999]).

Tieteellistä asiantuntijuutta tuotettiin kokemattomuus- ja opettajuusdiskurssin kautta. Yksi tämän tutkimuksen merkittävistä huomioista on, että tieteellinen asiantuntijuus oli ainoa asiantuntijuuden osa-alue, jota ei diskursiivisesti jaettu. Tieteellisen asiantuntijuuden nähtiin liittyvän tiukasti opettajuuteen, tutkimustyöhön ja yliopistolla työskentelyyn, eivätkä opiskelijat näyttäneet haluavan olla siinä osallisina. Se oli ikään kuin pyhää, vain akateemiseen opettajuuteen liittyvää. Näin selkeä tulos tieteellisen asiantuntijuuden jakamattomuudesta voi selittyä osittain tutkimusryhmällä: se muodostui sosiaalityön opiskelijoista, jotka olivat olleet työelämässä pitkään ja kiinnostuneet lisäämään teoriatietojaan koulutuksen avulla, jotta saisivat välineitä työhönsä. Diskursseissa he eivät olleet kiinnostuneita akateemisesta tutkimuksesta tai urasta vaan oman ammatillisuutensa kehittämisestä. Tämän vuoksi he eivät lähteneet haastamaan opettajan tieteellisen asiantuntijan roolia, mikä on ymmärrettävää, kun otetaan huomioon opettajan professioon liittyvät perinteet ja sidokset (Vuorikoski \& Räisänen, 2010). Sosiaalityöntekijäopiskelijoiden löyhempi sosiaalistuminen tiedeyhteisöön ja yliopistomaailmaan voi selittää, miksi he eivät osoittaneet diskursseissa kiinnostusta tieteellistä asiantuntijuutta kohtaan. Sosiaalityöntekijäopiskelijat sosiaalistuvat Ylijoen (1998) ja Rautiaisen (2003) mukaan enemmän ammattiin kuin tiedekuntaan, ja näin ammatillinen identiteetti rakennetaan tukevammin ammatillisuuden perustalle kuin akateemiseen maailmaan.

Selitys tieteellisen asiantuntijuuden jakamatta jäämiselle voi löytyä myös opettajista itsestään ja heidän omaksumistaan rooleista. Puhetapojen tutkimisen yhteydessä huomioni 
kiinnittyi usein erityisesti opettajien rooliin: opettajien tuottamista tieteellistä asiantuntijuutta kuvaavista diskursseista tuli esiin, miten opettajat käyttivät rooliaan hallitakseen tilannetta ja sen asiantuntijuutta mahdollisesti estääkseen oman professionsa arvovallan tai valtuutuksen menettämisen (vrt. Pärnä 2012, 42). Toisinaan he antoivat enemmän tilaa opiskelijoiden rooleille ja asiantuntijuudelle. Aiemmat tutkimukset opettajan identiteetistä ja roolista (Laurillard 2012; Tseng \& Kuo 2014; Heikkilä-Tammi \& Viteli 2017) tukevat tulkintojani opettajien roolien vaihtelusta. Tämä tuo esiin mielenkiintoisen aspektin: Kertooko tieteellisen asiantuntijuuden jakamattomuus ennemmin opettajien oman profession ydintehtävän suojelemisesta vai opiskelijoiden haluttomuudesta olla osallisena siinä? Niiden tilanteiden ja kontekstien löytäminen, joissa tieteellisen asiantuntijuuden diskursiivinen jakaminen mahdollistuu, lisäisi ymmärrystä asiasta.

Yhteistyö asiantuntijoiden välillä vaatii erilaisia välineitä ja kohtaamistiloja, jotka edesauttavat yhteisen tiedon tuottamista ja jakamista (Edwards 2010). Tutkimuksessani digitaalinen oppimisympäristö oli rajatyön (Edwards 2010) konteksti, joka mahdollisti toimijoiden kohtaamisen ja osaamisten yhdistämisen. On selvää, että opettajan ja opiskelijan suhde rajapintakohtaamisessa verkon välityksellä on epäsymmetrinen, eikä opiskelijoilla ole samoja valtaoikeuksia. Tulokulmani opettajien ja opiskelijoiden keskeisen asiantuntijuuden verkkoympäristössä tapahtuvan jakamisen tarkasteluun liittää keskustelun institutionaaliseen tasoon, jolloin valtasuhteiden olemassaoloa ei voida välttää. Pohtiessani tutkimustulosteni tulkintojen luotettavuutta minun on tarpeen nostaa valtasuhteet tietoiseen tarkasteluun (Pärnä 2012; Isoherranen 2012). Opettajalla on asiantuntijatietoon ja professioon liittyvää määrittelyvaltaa ja institutionaalisen sitoumuksensa vuoksi organisatoriseen asemaan sidottua päätösvaltaa. Tämä valta-asetelma selittää osaltaan, miksi opiskelijat eivät mahdollisesti halunneet haastaa opettajaa tieteellisessä asiantuntijuudessa. Jaettu asiantuntijuus ei kuitenkaan tarkoita valta-alueiden häivyttämistä tai sulauttamista yhteen (Edwards 2017). Ennemmin kyse on asiantuntijuuksien yhteensovittamisesta ja opettajan ja opiskelijan positioiden rajojen ylityksistä (ks. Isoherranen 2012; Koskela 2013; Jokinen ym. 2016). Opiskelijoiden ja opettajien haastattelupuheessa liikkui keskustelu omaan asiantuntijuuteen liittyvien asioiden ja asiantuntijuuden jakamisen vaateen välillä (Pärnä 2012).

Opettajat ja opiskelijat olivat huomattavan yksimielisiä asiantuntijuuden osa-alueista. Heidän tuottamansa määritelmät asiantuntijuudesta tukivat alkuperäistä käsitteenjakoani tieteelliseen, sisällölliseen ja teknologiseen asiantuntijuuteen. Rakentamieni osa-alueiden yli tai ohitse ei tuotettu puheessa muita asiantuntijuuden määreitä. Pitää kuitenkin huomioida, että muodostamieni haastattelukysymysten tematiikka on saattanut ohjata haastateltavia puhumaan ainoastaan tutkijan valitsemien temaattisten alueiden ja kysymysten mukaisesti, ja tämän vuoksi eriäviä sisältöalueita ei tuotu esiin. Analyysini tavoitteena ei ollut kontribuoida siihen, miten asiantuntijuutta käytännössä jaettiin, vaan tutkia haastattelupuheessa tuotettuja diskursseja asiantuntijuuden jakamisesta. Puhe on väline, joka mahdollistaa jaetun asiantuntijuuden ja ylläpitää sitä, minkä vuoksi puhetta on merkityksellistä tutkia. Näin puhe asiantuntijuudesta ja sen jakamisesta pysyy yllä ja tulee konstruoiduksi yhä uudelleen tutkimuksen avulla (Suoninen 1999, 106; Jokinen ym. 2016). Näin myös diskurssien elinvoimaisuus säilyy ja niiden siirtyminen käytännön toiminnaksi mahdollistuu. En tutkinut jaetun tai jakamattoman asiantuntijuuden taustalla piileviä syitä, vaan tutkimusta rajatakseni jätin ne ulkopuolelle. On huomioitava, että päätelmäni ja niistä kirjoittamani lopputulokset ovat myös diskurssien käyttöä (Fairlough 1992; Parker 1992) ja diskurssianalyysi on aina kontekstiinsa sidottua, joten haasteeksi tulee sen avulla analysoitujen tulosten teoreettinen yleistettävyys (Suoninen 1999). Haastateltavien määrä oli suhteellisen pieni, joten lisähaastattelut voisivat tuoda syvempää tietoa. Myös tutkimuksen toistaminen toisen tie- 
Opettajan asiantuntijuus muutoksessa-asiantuntijuus ja sen jakamisen diskurssit digitaalisessa oppimisympäristössä

teenalan opiskelijoiden kanssa voisi antaa lisätietoa. Pyrin kuvaamaan tutkimusprosessini mahdollisimman läpinäkyvästi tuomalla esille sen rajauksia ja heikkouksia; valitsin kuvaavimmat suorat aineistolainaukset tulkintojeni ja tutkimukseni luotettavuuden lisäämiseksi.

Tulkitsen tulokseni opettajan asiantuntijuuden muutoksesta mukaillen tutkimuskirjallisuudessa käytävää keskustelua professioiden jatkuvasta kehitysprosessista (ks. Pärnä 2012, 45; Wastiau 2013), jossa teknologialla on yhä suurempi rooli. Opettajan asiantuntijuus kulkee kohti monimuotoisempaa, jaetumpaa asiantuntijuutta (Tseng \& Kuo 2014; Michos \& Hernández-Leo, 2020). Kuitenkin on niin, että tieteellisyys, joka liittyy vahvaan yliopistoinstituutioon ja tiukasti akateemiseen professioon, ei ole kokenut diskursseissa tätä muutosta. Kallion (2015) mukaan yliopistojen toimintalogiikka ja yliopistojen ydintyö, tieteellinen tutkimus ja siihen perustuva opetus, ovatkin vuosisatojen kuluessa muuttuneet hyvin vähän ja edustavat edelleen syvälle institutionalisoitunutta yhteiskunnallisen toiminnan muotoa, jossa mestaristatuksen saavuttamiseen vie pitkä, vaativa polku. Opettajan asiantuntijuus ja professio ovat pysyvyydestään huolimatta muun muassa teknologian jatkuvan kasvun vuoksi joutuneet muutostilaan (Tseng \& Kuo 2014; Murtonen 2017; Michos \& HernándezLeo 2020). Opettajien tulee tulevaisuudessa pystyä yhdistämään pedagogisia ja teknologisia näkökulmia sekä jakamaan asiantuntijuuttaan samalla, kun he yrittävät hallita sen jatkuvaa muutosta (Laurillard 2012; Sannino \& Engeström 2017; Michos \& Hernández-Leo 2020). Opettajat tulevat tarvitsemaan tukea ja uudenlaisia rakenteita muutoksessa olevan asiantuntijuutensa käsittelemiseksi. Tähän haasteeseen vastaaminen edellyttää kuitenkin kattavampaa tutkimusta opettajien omista kokemuksista ja tulkinnoista siitä, miten opetusteknologia vaikuttaa opettajan työhön ja asiantuntijuuteen.

\section{Kirjallisuus}

Berger, Peter L. \& Luckmann, Thomas 1994. Todellisuuden sosiaalinen rakentuminen: Tiedonsosiologinen tutkielma. Helsinki: Gaudeamus.

Collin, Kaija 2010. Luovuus, oppiminen ja asiantuntijuus: Koulutuksen ja työelämän näkökulma. Helsinki: WSOY.

Conole, Gráinne 2013. Designing for learning in an open world. New York: Springer. https://doi.org/10.1007/978-1-4419-8517-0

D'Amour, Danielle, Ferrada-Videla, Marcela, San Martin Rodriguez, Leticia \& Beaulieu, Marie-Dominique 2005. The conceptual basis for interprofessional collaboration: Core concepts and theoretical frameworks. Journal of Interprofessional Care, 19 (1), 116-131. https://doi.org/10.1080/13561820500082529

Duhn, Iris, Fleer, Marilyn \& Harrison, Linda 2016. Supporting multidisciplinary networks through relationality and a sense of belonging: three "gardening tools" and the Relational Agency Framework. International Journal of Early Years Education, 24 (3), 378-391. https://doi.org/10.1080/09669760.2016.1196578

Edwards, Anne 2010. Being an Expert Professional Practitioner: The Relational Turn in Expertise. Dordrecht: Spinger. https://doi.org/10.1007/978-90-481-3969-9

Edwards, Anne 2017 (toim.). Working Relationally in and across Practices: A CulturalHistorical Approach to Collaboration. Cambridge: Cambridge University Press. https:// doi.org/10.1017/9781316275184

Eräsaari, Risto 2002. Avoimen asiantuntijuuden analytiikka. Teoksessa Pirttilä, Ilkka \& Eriksson, Susan (toim.), Asiantuntijoiden areenat. Jyväskylä: Jyväskylän yliopiston yhteiskuntatieteiden ja filosofian laitos, 21-35. 
Eteläpelto, Anneli \& Rasku-Puttonen, Helena 2005. Projektioppimisen haasteet ja mahdollisuudet. Teoksessa Eteläpelto, Anneli \& Tynjälä, Päivi (toim.), Oppiminen ja asiantuntijuus, Työelämän ja koulutuksen näkökulmia. Porvoo; Helsinki; Juva: WSOYpro, 1.-3. painos, 180- 205.

Fairclough, Norman 1992. Discourse and Social Change. Cambridge: Polity Press.

Gergen, Kenneth J. 1994. Realities and Relationships. Soundings in Social Construstion. Cambridge, MA: Harvard University Press.

Giddens, Anthony 1995. Elämää jälkitraditionaalisessa yhteiskunnassa. Teoksessa Beck, Ulrich, Giddens, Anthony \& Lash, Scott. Nykyajan jäljillä. Refleksiivinen modernisaatio. Tampere: Vastapaino, 83-152.

Gil-Flores, Javier \& Rodríguez-Santero, Javier \& Torres-Gordillo, Juan-Jésus 2017. Factors that explain the use of ICT in secondary-education classrooms: The role of teacher characteristics and school infrastructure. Computers in Human Behavior 68, 441-449. https://doi.org/10.1016/j.chb.2016.11.057

Heikkilä-Tammi, Kirsi \& Viteli, Jarmo 2017. Esipuhe. Teoksessa Mäkiniemi, Jaana-Piia, Ahola, Salla, Syvänen, Antti, Heikkilä-Tammi, Kirsi \& Viteli, Jarmo. Digitalisoituva koulu- hyvinvoivat opettajat? Miten edistää digitalisoitumista ja työhyvinvointia? Tampere: TRIM Research Reports 24.

Hirsjärvi, Sirkka \& Hurme, Helena 2011. Tutkimushaastattelu. Teemahaastattelun teoria ja käytäntö. Helsinki: Gaudeamus Helsinki University Press.

Husu, Jukka \& Toom, Auli 2010. Opettaminen neuvotteluna -oppiminen osallisuutena: opettajuus demokraattisena professiona. Teoksessa Kallioniemi, Arto, Toom, Auli, Ubani, Martin \& Linnansaari, Heljä. (toim.), Akateeminen luokanopettajuus: 30 vuotta teoriaa, käytäntöä ja maistereita. Turku: Suomen kasvatustieteellinen seura, 131-145.

Isoherranen, Kaarina 2012. Uhka vai mahdollisuus - moniammatillista yhteistyötä kehittämässä. Akateeminen väitöskirja. Helsinki: Helsingin yliopisto.

Jalkanen, Juha \& Taalas, Peppi 2015. Monimediaisen kielten opetuksen tutkimus: teknologian integroinnista pedagogiseen kehittämiseen. Teoksessa Jakonen, Teppo, Jalkanen, Juha, Paakkinen, Terhi, Suni, Minna (toim.), Kielen oppimisen virtauksia. AFinLAn vuosikirja. Jyväskylä: Suomen soveltavan kielitieteen yhdistyksen julkaisuja 73, 172-186.

Jokinen, Arja, Juhila, Kirsi \& Suoninen, Eero 2016. Diskurssianalyysi. Teoriat, perusteet ja käyttö. Tampere: Vastapaino.

Kallio, Tomi, J. 2015. Ammattilaisbyrokratiat tehokkuuden aikakaudella - Tasapainoilua asiantuntijaeetoksen ja tehokkuuspaineiden välillä. Akateeminen väitöskirja. Tampere: Tampere University Press.

Karvinen-Niinikoski, Synnöve 2009. Postmoderni sosiaalityö. Teoksessa Mäntysaari, Mikko, Pohjola, Anneli, Pösö Tarja \& Pohjola, Timo (toim.), Sosiaalityö ja teoria. Jyväskylä: PS-Kustannus, 131-159.

Keurulainen, Harri, Miettinen, Maarit \& Weissmann, Kirsti 2014. Ammatillinen opettaja liikkeessä - syitä ja seurauksia. Teoksessa Jokinen, Hannu, Taajamo, Matti \& Välijärvi, Jouni (toim.), Pedagoginen asiantuntijuus liikkeessä ja muutoksessa - huomisen haasteita. Jyväskylä: Jyväskylän yliopisto, Koulutuksen tutkimuslaitos, 25-36.

Kivimäki, Sanna 2006. Opettaja verkossa. Teoksessa Kivimäki, Sanna, Kinnunen, Merja \& Löytty, Olli (toim.), Tilanteen taju: Opettaminen yliopistossa. Tampere: Vastapaino, 183-190. 
Opettajan asiantuntijuus muutoksessa-asiantuntijuus ja sen jakamisen diskurssit digitaalisessa oppimisympäristössä

Korhonen, Vesa \& Koivisto, Mari 2007. Muuttuvat oppimisympäristöt ja yliopisto-opettajan asiantuntijuus. Teoksessa Korhonen, Vesa (toim.) 2007. Muuttuvat oppimisympäristöt yliopistossa? Tampere: Tampereen yliopistopaino Oy, 59-80.

Koskela, Seija 2013. "Mie teen vain oman työni". Toimintatutkimus moniammatillisen yhteistyön ja ohjaustoiminnan kehittämisestä. Akateeminen väitöskirja. Jyväskylä: Jyväskylän yliopisto.

Laaksonen, Inkeri 2016. Avaimia huomiseen? Aikuisopettajien käsityksiä ilmiöstä opettajuus ja teknologia. Tampere: Tampere University Press.

Launis, Kirsti \& Engeström, Yrjö 2005. Asiantuntijuus muuttuvassa työtoiminnassa. Teoksessa Eteläpelto, Anneli \& Tynjälä, Päivi (toim.), Oppiminen ja asiantuntijuus, Työelämän ja koulutuksen näkökulmia. Porvoo; Helsinki; Juva: WSOYpro, 1.-3.painos, 64-66.

Laurillard, Diana 2012. Teaching as a design science: Building pedagogical patterns for learning and technology. New Yourk, NY:Routledge. https://doi.org/ $10.4324 / 9780203125083$

Leinonen, Piritta, Järvelä, Sanna \& Häkkinen, Päivi 2006. Yhteisöllinen oppiminen ja tietoisuustyökalut hajautetun tiimityön kontekstissa. Teoksessa Toiviainen, Hannu \& Hänninen, Hannu (toim.), Rajanylitykset työssä. Yhteistoiminnan ja oppimisen uudet mahdollisuudet. Helsinki: PS-kustannus, 138-162.

Michos, Konstantinos \& Hernández-Leo, Davinia 2020. CIDA: A collective inquiry framework to study and support teachers as designers in technological environments. Computers and Education, 143. https://doi.org/10.1016/j.compedu.2019.103679

Murtonen, Mari 2017. Yliopisto-opetuksen tavoitteena korkeatasoinen oppiminen. Teoksessa Murtonen, Mari (toim.), Opettajana yliopistolla: Korkeakoulupedagogiikan perusteet. Tampere: Vastapaino, 17-39.

Nevgi, Anne, Kynäslahti, Heikki, Vahtivuori, Sanna, Uusitalo Annukka \& Ryti Katja 2002. Yliopisto-opettaja verkossa - taidot puntarissa. Helsinki: Helsingin yliopisto. [wwwlähde]. $\quad<\quad$ https://www.researchgate.net/publication/251804390_Yliopistoopettaja verkossa - taidot puntarissa $>$ (luettu 1.8.2019).

Parker, Ian 1992. Discourse Dynamics: Critical Analysis for Social and Individual Psychology. London: Routledge.

Parviainen, Jaana (toim.), 2006. Kollektiivinen asiantuntijuus. Tampere: Tampere University Press.

Parton, Nigel 2002. Postmodern and Constructive Approaches to Social Work. Teoksessa Robert Adams, Lena Dominelli \& Malcolm Payne (toim.), Social Work. Themes, Issues and Critical Depates. London: Palgrave Mcmillan, 237-245.

Patrikainen, Risto 2000. Opettajuuden laatu ja opettajan ammatin professiomuutos. Teoksessa Harra, Kimmo. Opettajan professiosta: Artikkelisarja. Helsinki: Okka-säätiö, 20-31.

Pelttari, Sanna, Lintunen, Pekka \& Mutta, Maarit 2017. Kielen oppimisen ja opettamisen teknologiat -kurssilla katse kohti tulevaa. Yliopistopedagogiikka 24 (2), 27-29.

Pärnä, Katariina 2012. Kehittävä moniammatillinen yhteistyö prosessina. Lapsiperheiden varhaisen tukemisen mahdollisuudet. Akateeminen väitöskirja. Turku: Turun yliopiston julkaisusarja.

Raitakari, Suvi 2002. Sosiaalityön marginaalistatus. Asiakkuus ja asiantuntijuus modernin ja postmodernin tulkintakehyksessä. Teoksessa Juhila, Kirsi, Forsberg, Hannele \& Roivainen, Irene. Marginaalit ja sosiaalityö. Jyväskylä: Jyväskylän yliopisto, 44-58. 
Rautiainen, Tarja 2003. Ohjaus ja sosiaalistuminen tiedeyhteisöön. Yliopistopedagogiikkaa kehittämässä - kokeiluja ja kokemuksia. Tampere: Tampere University Press, 121-139 [www-lähde]. < https://trepo.tuni.fi/handle/10024/68278 > (luettu1.8.2019).

Saaristo, Kimmo 2000. Avoin asiantuntijuus: ympäristökysymys ja monimuotoinen ekspertiisi. Jyväskylä: Jyväskylän yliopisto.

Sannino, Annalisa \& Engeström, Yrjö 2017. Relational agency, double stimulation and the object of activity: An intervention study in a primary school. Teoksessa Edwards, Anne (toim.), Working relationally in and across practices: Cultural-historical approaches to collaboration. Cambridge: Cambridge University Press, 58-77. https://doi.org/ $\underline{10.1017 / 9781316275184.004}$

Stenius, Minna, Hankonen, Nelli, Ravaja, Niklas \& Haukkala, Ari 2016. Why share expertise? A closer look at the quality of motivation to share or withhold knowledge. Journal of Knowledge Management 20 (2), 181-198. https://doi.org/10.1108/JKM-032015-0124

Suárez-Rodríguez, Jésus, Almerich Gonzalo, Orellana, Natividad \& Díaz-García, Isabel 2018. A basic model of integration of ICT by teachers: competence and use. Educational Technology Research and Development 66 (5), 1165-1187. https://doi.org/10.1007/ $\underline{\text { s11423-018-9591-0 }}$

Suoninen, Eero 1999. Näkökulma sosiaaliseen todellisuuteen. Teoksessa Jokinen, Arja, Juhila, Kirsi \& Suoninen, Eero (toim.), Diskurssianalyysi liikkeessä. Tampere: Vastapaino, 17-36.

Tseng, Fan-Chuan \& Kuo, Feng-Yang 2014. A study of social participation and knowledge sharing in the teachers' online professional community of practice. Computers \& Education 72, 37-47. https://doi.org/10.1016/j.compedu.2013.10.005

Tuomi, Jouni \& Sarajärvi, Anneli 2002. Laadullinen tutkimus ja sisällönanalyysi. Helsinki: Tammi.

Tynjälä, Päivi 2004. Asiantuntijuus ja työkulttuurit opettajan ammatissa. Kasvatus 35 (2), 174-190.

Tynjälä, Päivi 2006. Opettajan asiantuntijuus ja työkulttuurit. Teoksessa Nummenmaa, Anna Raija \& Välijärvi, Jouni. Opettajan työ ja oppiminen. Jyväskylä: Koulutuksen tutkimuslaitos, 99-122.

Vaherva, Tapio 2005. Henkilöstökoulutuksen rajat ja mahdollisuudet. Teoksessa Eteläpelto, Anneli \& Tynjälä, Päivi (toim.), Oppiminen ja asiantuntijuus: työelämän ja koulutuksen näkökulma. Porvoo; Helsinki; Juva: WSOYpro, 1.-3.painos, 83-101.

Valkeavaara, Tuija 2005. Ongelmien kauttako asiantuntijaksi? Henkilöstön kehittäjien kokemuksia työnsä ongelmallisista tilanteista. Teoksessa Eteläpelto, Anneli \& Tynjälä, Päivi (toim.), Oppiminen ja asiantuntijuus: työelämän ja koulutuksen näkökulma. Porvoo; Helsinki; Juva: WSOYpro, 1.-3.painos, 102-124.

Vuorikoski, Marjo \& Törmä Taina 2007. Opettaja peilissä - Katse ammatilliseen kasvuun. 1.-2. painos. Vantaa: Dark Oy.

Vuorikoski, Marjo \& Räisänen, Mirka 2010. Opettajan identiteetti ja identiteettipolitiikat hallintakulttuurien murroksissa. Kasvatus \& Aika 4 (4), 63-81.

Wastiau, Patricia, Blamire, Roger, Kearney, Caroline, Quittre, Valerie, Van de Gaer, Eva \& Monseur, Christian 2013. The use of ICT in education: A survey of schools in Europe. European Journal of Education 48, 11-27. https://doi.org/10.1111/ejed.12020

Ylijoki, Oili-Helena 1998. Akateemiset heimokulttuurit ja noviisien sosialisaatio. Tampere: Vastapaino. 
Opettajan asiantuntijuus muutoksessa-asiantuntijuus ja sen jakamisen diskurssit digitaalisessa oppimisympäristössä

YTM Jenni Huhtasalo työskentelee Turun yliopiston kauppakorkeakoulussa Porin yksikössä ja on jatko-opiskelija Tampereen yliopistossa sosiologian oppiaineessa. 


\section{Liite: Puolistrukturoidut teemahaastattelukysymykset opettajille ja opiskelijoille}

\section{Alkutilanne/vapaata keskustelua}

- Oliko sinulla aikaisempia käyttökokemuksia jostakin verkko-opetusohjelmasta ja jos oli, niin oliko näillä aikaisemmilla käyttökokemuksilla hyötyä omasta mielestäsi Adobe Connect Pron käytössä? (opiskelijoille ja opettajille)

- Jos ei ollut mitään aiempaa kokemusta verkko-opetuksesta niin millaiseksi koit työskentelyn Adoben kautta? (opiskelijoille ja opettajille)

- Minkälaiset tietotekniset taidot sinulla oli ennen Adobe Connect Pron käyttöä? Onko mielestäsi verkossa toimiminen ja tietotekniikan käyttö sinulle luontevaa? Mitä haasteita sinulla siinä mahdollisesti on? (opiskelijoille ja opettajille)

- Saitko mielestäsi riittävästi ohjausta Adoben käyttöön ennen verkkoseminaarikurssin alkua tai sen aikana jos koit tarvetta? (opiskelijoille ja opettajille)

- Saitko riittävästi ohjausta /informaatiota siitä, mitä verkkoseminaarissa tehdään, miten siinä edetään ja mitä se sinulta opiskelijana edellyttää? (opiskelijoille)

\section{Verkkoseminaarityöskentelyn toteutus/vapaata keskustelua}

- Mitkä asiat koit haastavina Adobe Connect Pron käytössä? (opiskelijoille ja opettajille)

- Toiko käytetty tekniikka joitakin ongelmia tai haasteita? (esim. toimivatko yhteydet aina hyvin, kuuluiko kaikkien ääni, toimivatko mikrofonit, kaiuttimet?) (opiskelijoille ja opettajille)

- Veikö tekniikka ja sen toimimaan saaminen mielestäsi liikaa aikaa? (opiskelijoille ja opettajille)

\section{Oppimisen tukeminen ja seminaarityön ohjaus/ vapaata keskustelua}

- Minkälaiseksi opettajan rooli muodostui opiskelijoiden oppimisen tukijana ja ohjaajana verkkoseminaarityöskentelyn aikana? (opiskelijoille)

- Saitko palautetta/kommentteja opettajalta verkkoseminaarityöskentelyn aikana? Ja oliko palautteen anto mielestäsi riittävää? (opiskelijoille)

- Oliko sellaisia tilanteita, että annoit opettajalle palautetta hänen toiminnastaan verkkoseminaarissa? Tai olisitko toivonut, että tällainen palauteosio olisi ollut? (opiskelijoille)

- Minkälaiseksi koit verkkoseminaarityöskentelyn opiskelijan näkökulmasta ja erityisesti oppimisen näkökulmasta? (opiskelijoille)

- Entä millaiseksi koit verkkoseminaarityöskentelyn ohjauksen näkökulmasta? Miten ohjaus sujui ja oliko se motivoivaa? (opiskelijoille)

- Miten oppimisen tukeminen ja ohjaus verkossa eroaa lähiseminaarityöskentelyn tukemisesta ja ohjauksesta? (opiskelijoille)

- Saitko verkkoseminaarityöskentelyn aikana myös yksilöohjausta? Olisitko kaivannut sitä? Jos sait, niin minkälaista? (opiskelijoille)

\section{Vuorovaikutus ja dialogi/vapaata keskustelua}

- Minkälaiseksi koit vuorovaikutuksen ja dialogin verkkoseminaarissa? Opettajan ja opiskelijoiden kesken sekä opiskelijoiden välillä? (opiskelijoille ja opettajille)

- Yhteisöllisen oppimisen ja toisaalta myös sen oman tutkimusprosessin kannalta omien ajatusten jakaminen muiden opiskelijoiden kanssa on hyvin oleellista. Vertaisoppiminen ja vuorovaikutus painottuvat. Miten tämä omien ajatusten jakami- 
nen toteutui verkkoseminaarissa? Ja miten vertaisoppiminen toteutui? (opiskelijoille ja opettajille)

- Saitko sanottua oman mielipiteesi ja näkökulmasi asioista? Pystyitkö vaikuttamaan keskusteluiden sisältöön ja vuorovaikutukseen? (opiskelijoille)

- Minkälaisena koit vuorovaikutuksen? Oliko vuorovaikutus avointa, helppoa ja luontevaa? Oliko keskusteluissa paljon passiivisia osallistujia? (opiskelijoille ja opettajille)

- Minkälaisena koit vuorovaikutuksen opettajan kanssa? (opiskelijoille)

- Miten mielestäsi ohjausta koskevan tiedon jakaminen mahdollistuu käytettäessä verkkoseminaaria ohjauksen ja opetuksen välineenä? (opiskelijoille ja opettajille)

- Oliko verkossa tapahtuva keskustelu ja vuorovaikutus vilkasta? (opiskelijoille ja opettajille)

- Koitko, että kaikilla oli yhtäläiset mahdollisuudet osallistua keskusteluun ja vuorovaikutukseen verkon välityksellä? (opiskelijoille ja opettajille)

- Mitä ajattelet, että miten muut kokivat vuorovaikutustilanteet Adoben kautta tapahtuvassa seminaarityöskentelyssä? (opiskelijoille ja opettajille)

- Koetko virtuaalisen yhteyden etäännyttävän opettajaa opiskelijoista verrattuna kasvokkain tapahtuvaan kohtaamiseen? (opiskelijoille ja opettajille)

- Millaisena koit De Bonon hattu-menetelmän käytön verkkoseminaarissa? (opiskelijoille)

\section{Asiantuntijuus/ vapaata keskustelua}

Alustus: Asiantuntijuutta on monenlaista ja monilla on asiantuntemusta useammasta aihealueesta. Jos ajattelemme tähän verkkoseminaarin toteutukseen liittyvää asiantuntijuutta opettajien ja opiskelijoiden kesken niin sieltä varmasti löytyy jokaiselta erilaista asiantuntijuutta, esimerkiksi joku osaa toimia teknologian kanssa ja toisella on sosiaalityön asiantuntijuutta ja tähän kanditutkimuksen tekemiseen liittyvää asiantuntijuutta, niin siltä pohjalta, mitä ajattelet, että:

- Minkälaiseksi koet opettajan ja opiskelijan asiantuntijuuden kun työskennellään verkon kautta? (opiskelijoille ja opettajille)

- Miten ja mitä asiantuntijuutta mielestäsi jaettiin verkossa opettajan ja opiskelijan kesken? Vai tapahtuiko siellä asiantuntijuuden jakamista? (opiskelijoille ja opettajille)

- Jaettiinko asiantuntijuutta mielestäsi opettajan ja opiskelijoiden kesken enemmän, tai jaettiinko sitä eri tavoin verkossa kuin ns. tavallisen lähiseminaarityöskentelyn aikana? (opiskelijoille ja opettajille)

- Mitkä asiat mielestäsi vaikuttavat asiantuntijuuden jakamiseen opettajan ja opiskelijoiden kesken? (opiskelijoille ja opettajille)

\section{Lopputilanne}

- Mitä lisäarvoa mielestäsi tämä käytetty menetelmä toi verrattuna perinteiseen kandiseminaarityöskentelyyn? Tai toiko mitään? (opiskelijoille ja opettajille)

- Minkälainen oli asenteesi /suhtautumisesi Adobeen ennen sen käyttöä ja käyttökokemuksen jälkeen? (opiskelijoille ja opettajille)

- Oliko oppiminen/opettaminen mielekästä? (opiskelijoille ja opettajille )

- Millaiseksi työvälineeksi koit verkkoseminaarityöskentelyn opinnäytetyön ohjauksessa? (opiskelijoille ja opettajille) 
- Toivoisitko jatkossa opiskelevasi/opettavasi Adoben välityksellä? (opiskelijoille ja opettajille)

- Mikä onnistui mielestäsi hyvin? (opiskelijoille ja opettajille)

- Mitä parantamisehdotuksia sinulla olisi? (opiskelijoille ja opettajille)

- Mitä haasteita tuli esiin? (opiskelijoille ja opettajille) 